\title{
The impact of political unrest in Ireland on Irish soldiers in the British army, 1914-18: a re-evaluation
}

\author{
Emmanuel Destenay* \\ University College Dublin
}

\begin{abstract}
A B STR ACT. In order better to understand the impact of political unrest in Ireland on Irish troops fighting in the First World War, it is necessary to acknowledge that the role of the 1916 Rising has been significantly overestimated, while the influence of the 1914 home rule crisis and the repercussions of the anti-conscription movement have been underestimated. The 1914 home rule crisis significantly impacted on the Germans' view of the Irish and conditioned the treatment of Irish P.O. W.s from December 1914 onwards. In addition, the post-1916 Rising executions and the conscription crisis had a severe impact on Irish front-line units, while also sapping the morale of other British combatants. The 1916 Rising might have been dismissed as a military operation conceived by a handful of republicans, with little support from the wider population, but the conscription crisis brought about widespread defiance towards British rule throughout the whole of nationalist Ireland. In line with British public opinion, British front-line officers and men strongly resented Ireland's refusal to support the war effort at such a crucial moment. The consequence was the widespread targeting and stigmatisation of their Irish comrades-in-arms. Some British officers and men resorted to a form of psychological pressure, aimed at the public shaming of Irish troops. This article draws on new primary sources available at The National Archives in London, Dublin City Archives and University of Leeds Library to argue that the 1916 Rising was not the only political event in Ireland to have repercussions for Irish battalions fighting in the First World War.
\end{abstract}

$\mathrm{T}$ he history of Irish participation in the First World War has an increasingly complex historiography. While initial research focused on military engagements involving Irish units, more recent work dealing with recruitment and the impact of the war on Ireland has gradually extended knowledge of Ireland's role in the conflict. ${ }^{1}$ Historians have also considered the reaction of

* Centre for War Studies, School of History and Archives, University College Dublin, emmanuel.destenay@wanadoo.fr

${ }^{1}$ Key works include: Cyril Falls, The history of the $36^{\text {th }}$ (Ulster) Division (London, 1922); Henry Harris, The Irish regiments in the First World War (Cork, 1968); Tom Johnstone, Orange, green and khaki: the story of the Irish regiments in the Great War, 1914-18 (Dublin, 1992); Terence Denman, Ireland's unknown soldiers: the $16^{\text {th }}$ (Irish) Division in the Great War (Dublin, 1992); David Fitzpatrick (ed.), Ireland and the First World War (Dublin, 1986); Thomas Hennessey, Dividing Ireland: World War One and partition (London, 1998); Keith Jeffery, Ireland and the Great War 
front-line Irish nationalist and unionist officers to the 1916 Rising and its aftermath. Their findings have illustrated that the reaction of Irish officers to the events of 1916 varied greatly according to their political beliefs but that, overall, the wartime experiences of Irish battalions never significantly contrasted with those to be found within the British Expeditionary Force. ${ }^{2}$ These conclusions are somewhat unsatisfactory, as insufficient attention has been given to the reaction of front-line infantry soldiers. To deal only with the reaction of front-line officers necessarily offers an incomplete picture. Furthermore, a wider perspective is necessary if we are to apprehend more fully the impact of political upheavals in Ireland on front-line Irish battalions. Political unrest in Ireland moulded the perception of Irish units among other combatants, exposing Irish battalions to pressure. In addition to the 1916 Rising and its aftermath, the 1914 home rule crisis impacted upon the internment of Irish prisoners of war, while the 1917-18 conscription crisis influenced the war experiences of infantry soldiers and officers alike.

The present article draws on a range of new primary sources to assess the impact of political unrest in Ireland on Irish soldiers. A thorough analysis of the 'Report of prisoner of war camp at Limburg and the attempted formation of a so-called Irish brigade', coupled with an assessment of the interviews and reports compiled by the Committee on the Treatment of British Prisoners of War lends support to the hypothesis that the internal turmoil in Ireland had a more significant impact on the war experiences of Irish P.O.W.s than has been assumed to date. ${ }^{3}$ Additional information gathered from the Monica Roberts Collection offers evidence of the reactions of Irish units to the 1916 Rising. In the light of the testimonies written by soldiers for their war godmothers, there is ample indication that the anti-conscription movement in Ireland undertook a campaign aimed at fostering a climate of mistrust of Irish battalions and had a significant impact on them. Drawing on the private correspondence of Irish chaplains, located at the Irish Jesuit Archives in Dublin, and on the personal diaries of British officers and men held in the Liddle Collection at the University of Leeds Library, it is possible to conclude that the 1917-18 anti-conscription campaign had an impact on some British officers and men fighting in France, who were led to voice their indignation at their Irish comrades. This adds weight to the view that 'the Easter Rising of 1916 has for too long overshadowed what was in fact a more important political event, that of the 1917-1918 Conscription crisis'. ${ }^{4}$ More generally, the evidence indicates

(Cambridge, 2000); Ben Novick, Conceiving revolution: nationalist propaganda during the First World War (Dublin, 2001); Jérôme aan de Wiel, The Catholic church in Ireland, 1914-1918: war and politics (Dublin, 2003); John Horne (ed.), Our war: Ireland and the Great War (Dublin, 2008); Catriona Pennell, A kingdom united: popular responses to the outbreak of the First World War in Britain and Ireland (Oxford, 2012), Jason Myers, The Great War and memory in Irish culture, 1918-2010 (Dublin, 2013).

2 Jane Leonard, 'The reaction of Irish officers in the British army to the Easter Rising of 1916' in Cecil Hugh and Peter Liddle (eds), Facing Armageddon: the First World War experienced (London, 1996), p. 266; Lynn Lemisko, 'Morale in the 16th (Irish) Division, 1916-1918' in Irish Sword, xx (1997), p. 230.

3 'Report of prisoner of war camp at Limburg and the attempted formation of a socalled Irish Brigade', 1921 (T.N.A., WO 141/49); Committee on the Treatment of British Prisoners of War: interviews and reports, 1914-19 (T.N.A., WO 161/98-101).

${ }^{4}$ Aan de Wiel, The Catholic church in Ireland, p. 330. 
that historians have tended to overestimate the impact of the 1916 Rising and to underestimate the influence of the 1914 and the 1917-18 crises on Irish troops fighting in the First World War.

In order to re-evaluate the impact of political unrest in Ireland on Irish soldiers in the First World War, this article will begin by considering briefly the expectations and motivations of Irish recruits in the British army. The article will then examine the manner in which the home rule crisis shaped German attitudes towards Irish P.O.W.s. The next section of the article aims to demonstrate that political events in Ireland in 1916 had considerable repercussions for Irish battalions. Finally, and most importantly, the article addresses the impact of the post-Rising executions and the conscription crisis. In general, the evidence indicates that while some British units did register the consequences of the 1916 Rising, some of them began targeting their Irish brothers-in-arms after Irish M.P.s reaffirmed their opposition to conscription. Several Irish units experienced pressure from their British brothers-in-arms during the conscription crisis in Ireland and faced widespread suspicion from British troops. Consequently, the conscription crisis resulted in the singling out of Irish units, contributed to their unease and exposed them to the resentment of other combatants of the British army.

The First World War experiences of Irish units cannot properly be studied without taking into account the impact of political unrest in Ireland. In January 1913, unionists raised an armed militia, the Ulster Volunteer Force (U.V.F.), to counter the threat of home rule. ${ }^{5}$ A pragmatic convergence of interests gradually fostered a de facto alliance with Germany. On 24 April 1914, 35,000 rifles and rounds of ammunition arrived in Larne harbour from Germany. ${ }^{6}$ Three months later, on 26 July, proponents of home rule who had founded the Irish Volunteers (a paramilitary organisation ready to oppose the Ulster Volunteer Force) awaited the arrival of 2,500 rifles and 176,000 rounds of ammunition from Germany. Before the outbreak of the war, therefore, Germany had lent support to both nationalist and unionist paramilitary organisations. In July 1914, two citizen armies were preparing for civil war in Ireland.

Great Britain's declaration of war on Germany, on 4 August 1914, and the British authorities' decision to postpone home rule for the duration of the war, complicated the strategies of nationalist and unionist militias, which found themselves more or less compelled to support Britain's call to arms and could no longer rely on covert German support. Many Irish nationalists believed firmly that backing Britain would help them to secure home rule. By contrast, staunch unionists hoped their own display of loyalty would cement their attachment to the United Kingdom. They enlisted therefore in the hope that this would prevent the establishment of a Dublin parliament to which Ulster would be constitutionally bound. ${ }^{7}$ Of course, not all Catholic army recruits were motivated by a nationalist agenda, nor did all Protestant volunteers fight

${ }^{5}$ Richard Grayson, Belfast boys: how unionists and nationalists fought and died together in the First World War (London, 2009), p. 1.

${ }_{7}$ Harris, The Irish regiments, pp 8-9.

7 Pennell, A kingdom united, p. 194. 
in order to oppose home rule. The invasion of Belgium had a considerable impact on the motivations of Irish recruits. ${ }^{8}$ The war furthermore provided an opportunity for men in their prime to live a unique experience and to confront the unknown in foreign lands. ${ }^{9}$ Economic considerations also came into play, as many men volunteered because of unemployment and low pay. ${ }^{10}$ This goes at least some way to explaining the 132,202 volunteers who enlisted between August 1914 and November 1918, in addition to the 20,000 Irish officers and men already serving in the British army, and the 30,000 reservists ready for mobilisation. ${ }^{11}$

On 21 August 1914, the War Office raised the $10^{\text {th }}$ (Irish) Division, the first British corps with an Irish name. Unfortunately, few testimonies remain from recruits enrolled in the $10^{\text {th }}$ Division. Following its landing in Gallipoli on 6 August 1915, the unit was reduced by 'nearly 75 per cent of its original strength' which helps to explain the scarcity of memoirs available today. ${ }^{12} \mathrm{On}$ 11 September 1914, the War Office authorised the formation of the $16^{\text {th }}$ (Irish) Division and appointed Sir Lawrence Parsons, an Irish Protestant who was 'no supporter of the cause of constitutional Irish nationalism', as commanding officer. Whereas 85 per cent of officers commissioned were Protestant, 98 per cent of the infantry soldiers were Catholic. ${ }^{13}$ Only four out of eleven officers of a battalion of the Leinsters were Catholics. ${ }^{14}$ Sir Francis Vane, who recruited for the $9^{\text {th }}$ Royal Munster Fusiliers, mentioned a few Catholic second officers in the $16^{\text {th }}$ Division, whereas in the $8^{\text {th }}$ Royal Munster Fusiliers almost all the officers were of Protestant denominations. ${ }^{15}$ While the $16^{\text {th }}$ Division is commonly seen as being formed from Irish Volunteers, it should be noted that it was really only the $47^{\text {th }}$ Brigade which was cleared to allow drafts from that group. ${ }^{16}$ Battalions such as the $9^{\text {th }}$ Royal Dublin Fusiliers ( $48^{\text {th }}$ Brigade) did indeed have 'a more nationalist ethos', but the majority were clearly not involved in any political battle. ${ }^{17}$ The War Office agreed to raise the last Irish division, the $36^{\text {th }}$ Ulster Division, on 28 October 1914. Political connections between the government and the Ulster Volunteer Force helped unionist

${ }^{8}$ Catriona Pennell, 'Going to war' in John Horne (ed.), Our war: Ireland and the Great War (Dublin, 2008), p. 41.

9 John Morrissey, 'A lost heritage: the Connaught Rangers and multivocal Irishness' in Mark McCarthy (ed.), Ireland's heritages: critical perspectives on memory and identity (Aldershot, 2005), p. 76.

${ }_{11}^{10}$ Jeffery, Ireland and the Great War, pp 18-19.

11 Statistics of the military effort of the British Empire during the Great War, 1914-1920 (London, 1922), p. 363; Report on recruitment in Ireland, 1916 (T.N.A., WO 162/27, Cd. 8168 , p. 2).

12 Bryan Cooper, The $10^{\text {th }}$ (Irish) Division at Gallipoli (Dublin, 1995), p. 255. At this point, the author has not identified any memoirs or letters from units with the $10^{\text {th }}$ Division in which soldiers express their feelings in the aftermath of the Rising or during the conscription crisis.

13 Denman, Ireland's unknown soldiers, pp 38-46.

14 Diary of Father McCrory, 1914-18 (P.R.O.N.I., D1868/1, p. 38).

15 Francis Vane, Agin the governments (London, 1929), p. 258; Father Joseph Wrafter to provincial, 2 Nov. 1915 (Irish Jesuit Archives, Correspondence of Father Wrafter, CHP1/63).

${ }_{17}$ Myers, The Great War, p. 13; Denman, Ireland's unknown soldiers, p. 127.

17 Timothy Bowman, The Irish regiments in the Great War: discipline and morale (Manchester, 2004), p. 127. 
volunteers to obtain commissions in the $36^{\text {th }}$ (Ulster) Division, as unionist leaders had previously secured a deal with the War Office 'that the UVF could join the army by regiment, with a guarantee that they would be kept together and that the UVF's officers would, where possible, become the officers of the new British army battalions formed as part of the $36^{\text {th }}$ Division' ${ }^{18}$ Consequently, battalions such as 'the $9^{\text {th }}$ Royal Irish Rifles [were] formed from the West Belfast Ulster Volunteer Force, and the $6^{\text {th }}$ Connaught Rangers and the $7^{\text {th }}$ Leinsters compris[ed] many Belfast nationalists' in their ranks. ${ }^{19}$ The kaleidoscopic political composition of the Irish battalions explains the contrasting reactions of front-line Irish infantry officers and men to political unrest in Ireland during the war.

\section{II}

The 1914 home rule crisis and the possibility of the outbreak of civil war in Ireland had aroused the attention of the German government which tended to regard Irish units as though they represented two homogenous entities. This led the German authorities to envisage that nationalist volunteers would betray their British uniform and enlist in the German army. Regular Irish troops experienced the repercussions of the home rule crisis directly as soon as they entered the war. Indeed, whereas the three newly-raised Irish divisions left Great Britain for the continent at the end of 1915, regular Irish units had landed with the British Expeditionary Force in August 1914 and became the first troops affected by the Irish political situation. In September 1914, banking on the neutrality of the United States, Sir Roger Casement, acting as a representative of Irish republicans, met Captain Franz von Papen at the German embassy in New York to discuss the creation of an Irish brigade in the German army. ${ }^{20}$ On 2 November, Arthur Zimmerman, state secretary for foreign affairs, invited Casement to Berlin. ${ }^{21}$ This unofficial alliance between the German authorities and Irish rebels was clearly a factor in the decision by the Germans to reserve specific treatment for Irish prisoners of war. ${ }^{22}$ This had consequences for regular Irish units who arrived in France with the British Expeditionary Force in August 1914. They became the first troops to be affected by the existence of a covert pact between Germany and Irish republicans.

In the early months of the conflict, Germans treated Irish P.O.W.s like other detainees. During the fight at Grand-Fayt, on 26 August 1914, the $2^{\text {nd }}$ Connaught Rangers lost one officer, with 14 men killed, and 5 officers and 180 men taken prisoner. At Maroilles, on 27 August, German units surprised and captured Lieutenant Colonel Abercrombie and his men from the Connaught

18 Grayson, Belfast boys, p. 11.

19 Ibid., p. xvi.

20 Jérôme aan de Wiel, The Irish factor, 1899-1919: Ireland's strategic and diplomatic importance for foreign powers (Dublin, 2010), p. 165.

${ }^{21}$ Charles Tansill, America and the fight for Irish freedom, 1866-1922 (New York, 1957), p. 178. See also One bold deed of open treason: the Berlin diary of Roger Casement, 1914-1916, ed. Angus Mitchell (Dublin, 2016).

${ }_{22}$ Emmanuel Destenay, 'La captivité des combattants irlandais de la Première Guerre mondiale: propagande de guerre, transferts de loyauté et résistances' in Revue historique, no. 678 (Apr. 2016), pp 323-43. 
Rangers. ${ }^{23}$ In the vicinity, men of the $2^{\text {nd }}$ Royal Munster Fusiliers were holding off the enemy to allow British units to retreat from Mons. A considerable number of these men fought bravely before finally surrendering. ${ }^{24}$ Between August and December 1914, German authorities grouped Irish P.O.W.s with other British P.O.W.s. However, from December 1914 onwards, German authorities systematically separated Irish regular soldiers and officers from their British brothers-inarms. $^{25}$ The Germans were seeking a strategy to exploit the historical tensions between Great Britain and Ireland, now that war had broken out. All Irish detainees were grouped together with the aim of raising an Irish brigade that could participate in a national uprising in Ireland. Long before the events of 1916, therefore, the German authorities hoped that nationalists within regular Irish units would transfer allegiance to the German army.

From December 1914 onwards, the German Military Staff held Irish P.O.W.s together in the Limburg an der Lahn camp, thereby hoping to 'recruit ... 200 to 300 men'. ${ }^{26}$ Approximately 1,500 Irish P.O.W.s arrived at Limburg from Sennegaler in December 1914. William Arthur, a soldier from Cheshire captured with the Royal Munster Fusiliers, saw the Germans crowding all the Irish soldiers into separate huts. ${ }^{27}$ John Beattie, 1st Gordon Highlanders, recalled seeing Irish prisoners 'taken out and marched to a separate part of the camp, and ... kept in a tent by themselves', isolated from other British and Allied soldiers. ${ }^{28}$ Ryan Robert, who arrived at the Limburg camp on 1 December 1914 along with 280 other soldiers, rejoiced at the abundant rations of food given to Irish prisoners. ${ }^{29}$ Michael Keogh marvelled at those 'fine wooden huts, well ventilated, comfortable [with] wooden trestles, and ample blankets' ${ }^{30}$ Prisoners nonchalantly read newspapers, played football and smoked outside their huts. ${ }^{31}$

Gradually, the Irish P.O.W.s grasped the intentions of the Germans. Three weeks after their arrival at Limburg, a handful of Irish republicans visited them. ${ }^{32}$ Thomas Fahey, from Carrick-on-Suir, remembered Sir Roger Casement speaking up in favour of a German victory. ${ }^{33}$ Meanwhile, both the German authorities and Irish republicans proceeded to recruit volunteers from the ranks of Irish prisoners. Other soldiers openly expressed their

23 Johnstone, Orange, green and khaki, p. 23.

24 Harris, The Irish regiments, p. 34.

25 Report of Arthur Williams, 1 Jan. 1914-31 Dec. 1918 (T.N.A., Committee on the Treatment of British Prisoners of War, WO 161/98/385, p. 225).

${ }^{26}$ Memorandum by Sir Roger Casement on the Irish brigade, 7 May 1915 (N.L.I., MS 13,085/7a).

27 Report of Arthur Williams, 1 Jan. 1914-31 Dec. 1918 (T.N.A., Committee on the Treatment of British Prisoners of War, WO 161/98/385, p. 225).

${ }_{28}$ Report of John Beattie, Aug. 1915-Feb. 1919 (T.N.A., Committee on the Treatment of British Prisoners of War, Index 3, WO 161/101/108).

29 Report of Ryan Robert, 20 Oct. 1914 (T.N.A., Committee on the Treatment of British Prisoners of War, WO 161/100/6, pp 2414-15).

${ }^{30}$ Memorandum by Sir Roger Casement on the Irish brigade, 7 May 1915 (N.L.I., MS 13,085/7a).

31 Report of John Holden, 4 Sept. 1914 (T.N.A., Committee on the Treatment of British Prisoners of War, WO 161/98/267, pp 140-1).

32 Report of Ryan Robert, 20 Oct. 1914 (T.N.A., Committee on the Treatment of British Prisoners of War, WO 161/100/6, pp 2414-15).

33 Report of Thomas Fahey, 1 Jan. 1914-31 Dec. 1918 (T.N.A., Committee on the Treatment of British Prisoners of War, WO 161/98/330, p. 183). 
disagreement by booing and insulting them. ${ }^{34}$ Still others, such as Sergeant Murphy, $2^{\text {nd }}$ Royal Munster Fusiliers, 'picked up some mud from the ground and threw it in Roger Casement's face'. ${ }^{35}$ The outrage of the Irish prisoners took various forms, leaving the Germans in no doubt as to where their loyalties lay. The Germans projected onto the regular Irish battalions their own perceptions of Irish political allegiances, in the absence of a more precise understanding of the 'diversity of Irishness'. ${ }^{36}$ The Germans wrongly viewed Irish troops as a single entity and, moreover, failed to grasp the manner in which the promise of home rule served as a channel for constitutional nationalism. Indeed, most regular officers and men who had nationalist sympathies embraced its constitutional variety, in the knowledge that the only way to secure a devolution of powers rested with a British victory in the war. ${ }^{37}$ The resistance of Irish prisoners led to the imposition of two weeks' punishment and a reduction of the daily bread ration from 750 to 300 grams. ${ }^{38}$ After a few weeks, the Germans again halved rations and began putting prisoners to work. According to one Transport Medical Officer, eighty prisoners starved to death rather than put on German uniforms between January and July $1915 .{ }^{39}$ Whereas Irish soldiers had benefited from special treatment upon their arrival, conditions deteriorated subsequently. ${ }^{40}$ The recourse to collective punishment was usually intended 'to exert pressure on the opposing state', collective reprisals in this case were a ploy intended to break the prisoners' loyalty to the British army. ${ }^{41}$

The Irish political situation shaped the Germans' view of Irish combatants from the start of the war. In this sense, internal political unrest in Ireland influenced the wartime experiences of Irish troops before the Easter Rising. Therefore, the Easter Rising cannot be identified as the first internal Irish event to impact directly on Irish First World War combatants. The evidence indicates that the home rule crisis had consequences for the treatment of Irish prisoners of war from the start. The German decision to view Irish troops as potential allies, coupled with the infliction of various forms of physical and moral abuse, forced P.O.W.s to draw upon their personal resources to summon up the capacity to resist. When the Germans realised that the Irish had not been won over by the propaganda aimed at them, their treatment worsened. The Germans did manage, with considerable difficulty, to mobilise around fifty members for their Irish brigade, but they were not shipped to Ireland. When the 1916 rebellion broke out, no Irish P.O.W. participated in the events of Easter week. ${ }^{42}$

34 Report of Tim McCarthy, 1 Jan. 1914-31 Dec. 1918 (T.N.A., Committee on the Treatment of British Prisoners of War, WO 161/98/331, p. 184).

35 Irish Soldier, 16 Oct. 1918.

36 Morrissey, 'A lost heritage', p. 71.

37 Ibid., p. 77.

38 Report of Ryan Robert, 20 Oct. 1914 (T.N.A., Committee on the Treatment of British Prisoners of War, WO 161/100/6, pp 2414-15).

39 Report of John Cecil, Aug. 1915-Feb. 1919 (T.N.A., Committee on the Treatment of British Prisoners of War, Index 3, WO 161/101/108).

40 Report of Joseph Mahoney, 29 Aug. 1914 (T.N.A., Committee on the Treatment of British Prisoners of War, WO 161/98/119, pp 48-9).

${ }^{41}$ Stéphane Audoin-Rouzeau and Annette Becker, 14-18, retrouver la guerre (Paris, 2000), p. 122.

42 Destenay, 'La captivité des combattants irlandais', p. 326. 
'Nothing saddened the [soldiers with the $2^{\text {nd }}$ Royal Irish Rifles] more than news of the Rising', confessed their chaplain, Father Gill. ${ }^{43}$ The Easter Rising erupted in Dublin on 24 April 1916 and ended in failure five days later. ${ }^{44}$ The multifaceted and conflicting reactions of front-line Irish troops to the uprising epitomises their multiple allegiances. A regular Irish soldier of the British Expeditionary Force wrote that 'there [was] no one more sorry to hear of the rising than the Irish troops' ${ }^{45}$ Regular soldiers with the $2^{\text {nd }}$ Royal Dublin Fusiliers felt that the insurrection had 'disgraced their country'. ${ }^{46}$ In addition to their disbelief, Irish soldiers worried about their families in Ireland. ${ }^{47}$ The resulting anguish added considerably to the prevailing level of stress among the troops. Many feared for their relatives' safety, especially in cases where families lived close to the streets were clashes had occurred. The lack of reassuring news from relatives further undermined the soldiers' morale. ${ }^{48}$ Christopher Fox, a regular front-line private, confessed: 'those murderers when I think of them it makes my blood run cold. I think of some poor fellows out here fighting for their country and them murdering cowards I suppose have killed some of their mothers and fathers or their wives and children as the case may be'. ${ }^{49}$ Frustration gripped soldiers who were enraged at their inability to engage the rebels. Regular Irish soldiers 'would [have] like[d] nothing better than to see the rebels sent to the front'. ${ }^{50}$ Meanwhile front-line soldiers asserted that the British government 'should shoot the lot of them straight off' ${ }^{51}$ One soldier expressed the wish that his unit could leave the front line to go to Dublin in order 'to exterminate the blighters' ${ }^{52}$ British officers serving in Irish units noted an equally strong condemnation on the part of their soldiers. ${ }^{53}$

Recruits to the $36^{\text {th }}$ Ulster Division felt extremely resentful when they learned of the rebellion that had broken out in Ireland. Soldiers with the $14^{\text {th }}$ Royal Irish Rifles 'recruited from the Young Citizen Volunteers, an initially non-political body, which had become aligned with Unionism', pointed out that as far as they were concerned, they would have preferred to "see less pity for ... these insurgent dogs who [had taken] advantage of the troops being absent ... to loot, rebel and murder crowds of innocent people'. 'I 'I suppose they will hang all the ring-leaders. It's what

43 Father Gill to provincial, 5 May 1916 (Irish Jesuit Archives, Correspondence of Father Gill, CHP 1/25).

${ }^{44}$ Royal commission on the rebellion in Ireland: minutes of evidence and documents relative to the Sinn Féin movement, ix [Cd 8279], H.C. 1916, 9.

45 Joseph Clarke to Monica Roberts, 22 Apr. 1916 (Dublin City Archives (D.C.A.),

Monica Roberts Collection, vol. i, RDFA/001/01).

46 Christopher Fox to Monica Roberts, 12 May 1916 (ibid., vol. ii, RDFA/001/14).

47 Thomas Finn to Monica Roberts, 13 June 1916 (ibid., vol. ii, RDFA/001/15).

48 Christopher Fox to Monica Roberts, 12 May 1916 (ibid., vol. ii, RDFA/001/14).

49 Christopher Fox to Monica Roberts, 31 May 1916 (ibid., vol. ii, RDFA/001/14).

50 Joseph Clarke to Monica Roberts, 11 May 1916 (ibid., vol. i, RDFA/001/01).

51 George Soper to Monica Roberts, 20 May 1916 (ibid., vol. iv, RDFA/001/2).

52 Memoirs of Second Lieutenant Butler, 27 Apr. 1916 (University of Leeds Library (U.L.L.), Liddle Collection, GS 0253).

${ }_{53}$ Second Lieutenant R. B. Marshall to his mother, 4 May 1916 (U.L.L., Liddle Collection, GS 1056).

${ }^{54}$ Grayson, Belfast boys, p. 13; The Incinerator, 1 June 1916. 
the traitors deserve', wrote Lieutenant Patrick Hemphill. He added: 'The beauty of the thing is that they will all be tried by court-martial which has no lenient tendencies. ${ }^{55}$ The Ulster Division's indignation consisted in displays of their loyalty to the empire: to denounce the treason of the republicans was to prove their British affiliation. The dreadful spectre of a handful of rebels endeavouring to overthrow British rule in Ireland appalled unionist units elsewhere. In Alexandrovsk, on the eastern front, the Royal Naval Armoured Car Squadron (R.N.A.S.) experienced difficulties in the aftermath of the rebellion. Operating in isolation from other British troops and fighting alongside the Russian army, 'a small minority, inflamed by a diet of illegally hoarded rum and barrack-room rhetoric, demanded repatriation at once. When told that it was impossible they became angry, threatening to .... sail to Ireland themselves. For a while they were beyond their officers' control. ${ }^{56}$ The Ulster Volunteer Force had strong ties with the R.N.A.S. and had encouraged Irish unionists to enrol in the unit. Under the effect of alcohol, unionist volunteers envisaged returning to Ireland in order to quash the Rising.

'I will never forget the men's indignation [when they heard about the rebellion]. They felt they had been stabbed in the back', confessed a fervent nationalist officer with the Connaught Rangers. ${ }^{57}$ The voluntary recruits of the $16^{\text {th }}$ Division had, to some extent, enlisted because they anticipated the introduction of home rule after the conflict. After the Rising, advocates of home rule realised that the events of Easter week had weakened constitutional nationalism. ${ }^{58}$ William Redmond, brother of the leader of the Irish Parliamentary Party, collapsed on hearing news of the Rising, 'sobbing bitterly like a child'. ${ }^{59}$ However, voluntary recruits and regular soldiers of the British Expeditionary Force also condemned the executions of the ringleaders. A sergeant with the $2^{\text {nd }}$ Royal Irish Rifles, while he denounced the rebels, nonetheless disagreed with the executions of the leaders: 'My fellow soldiers had no great sympathy with the rebels, but they got fed up when they heard of the executions of the leaders. I experience a cold fury, because I would see the whole British Empire damned sooner than hear of an Irishman being killed in his own country by any intruding stranger. ${ }^{60}$ Fresh executions ignited consternation among regular soldiers of the $2^{\text {nd }}$ Royal Irish Rifles, who ultimately denounced the repression of the insurgents. Not only did they question the legitimacy of the executions, they also objected to the British presence in Ireland. Harry Loughlin, an Irish soldier with a British Expeditionary Force unit, confessed that he did not 'in the least sympathise with the sentences passed upon the Sinn Féiners' ${ }^{61}$ Several volunteers went as far as to call into question their part in the war effort

${ }^{55}$ Lieutenant R. P. Hemphill to his parents, 29 Apr. 1916 (U.L.L., Liddle Collection, GS 0741).

56 Bryan Perrett and Anthony Lord, The Czar's British squadron (London, 1981), p. 43.

57 Leonard, 'The reaction of Irish officers', p. 263.

58 Stephen Gwynn, John Redmond's last years (London, 1919), pp 230-31.

59 Terence Denman, A lonely grave: the life and death of William Redmond (Dublin, 1995), p. 97.

60 John Lucy, There's a devil in the drum (London, 1938), p. 352.

${ }^{61}$ Harry Loughlin to Monica Roberts, 17 June 1917 (D.C.A., Monica Roberts Collection, vol. i, RDFA/001/02). 
on the British side: 'It was a rude awakening, guns being fired at the people of my own race by soldiers of the same army with which I was serving., ${ }^{62}$ Nationalist recruits began to weigh the implications of their enlistment. Their commitment to the British crown by no means implied unconditional loyalty. As Thomas Hennessy has pointed out, in relation to the aftermath of the 1916 Rising, 'When the British authorities responded with coercive measures, these could more easily be associated with older and stronger nationalist myths of British oppression. ${ }^{\text {'63 }}$ In short, there is evidence to suggest that the rebels' executions caused indignation among nationalist recruits and among Irish soldiers who were members of the British Expeditionary Force.

Almost all the comments on the part of nationalist Irish soldiers condemning the executions of the 1916 rebels and expressing a sense of angst in reaction to the repression carried out by the British Government are to be found in memoirs published after the First World War. It would be unwise to engage in a study of the reaction of Irish troops without acknowledging this point. Soldiers could not always articulate their sense of despair and frustration at the time. Irish soldiers in units commanded by English, Canadian or South African officers such as the $7^{\text {th }}$ Leinsters, the $6^{\text {th }}$ Connaught Rangers, and the $9^{\text {th }}$ Royal Dublin Fusiliers certainly refrained from expressing their political views publicly. The intriguing silence of some battalions might in part be explained by the soldiers' reluctance to reveal their personal views before their commanding officers. Only after the war did they feel entitled and safe to confess what they had felt in the aftermath of the Rising. In addition, the 'military censor sometimes monitored the mail of Irish soldiers with a view to uncovering "disloyal" sentiments'. ${ }^{64}$ This might explain the absence of pro-Rebellion testimonies. Whether influenced by a mechanism that prevented their openly giving voice to their support for the rebels, or as a result of a genuine indifference to the events in Ireland, the silence of some Irish soldiers and officers must be decrypted. Bearing in mind that 'Irish soldiers were tried by court martial for offences where an English soldier would simply have appeared before his CO', ${ }^{65}$ Irish nationalists might have internalised their sympathies for the 1916 rebels from fear of possible repercussions. Furthermore, the mistrust of the British authorities, who feared a possible breach of duty by Irish units, equally contributed to the silence and the unease of Irish units.

On 28 April 1916, the British Government forbade front-line Irish soldiers from returning to Ireland on leave. ${ }^{66}$ The military staff ordered the $2^{\text {nd }}$ Royal Irish Regiment to stay in reserve for two weeks for fear of an adverse front line reaction. ${ }^{67}$ The $1^{\text {st }}$ Royal Munster Fusiliers, fighting alongside the $86^{\text {th }}$ Brigade of the $29^{\text {th }}$ Division at Messines, suddenly left the front lines for the rear. ${ }^{68}$

62 Tom Barry, Guerrilla days in Ireland (Dublin, 1949), p. 1.

63 Thomas Hennessy, Dividing Ireland: World War One and partition (London, 1998), p. 237.

${ }_{64}$ Denman, Ireland's unknown soldiers, p. 142.

65 Bowman, The Irish regiments, p. 202.

66 Telegram from Dublin Castle to the War Office, 28 Apr. 1916 (T.N.A., Employment of military forces: Irish rebellion, WO 32/4307).

${ }^{67}$ War diary of Anthony Brennan, 1915-17 (Imperial War Museum, London, P262, p. 7).

68 Regimental diary of 86 Infantry Brigade, General staff report, 24 Apr. 1916 (T.N.A., WO 95/2298). 
In May 1916, the $16^{\text {th }}$ Division received 'an unusual number of visits from highranking officers' travelling from England to gauge the morale of the battalions. ${ }^{69}$ In June 1916, the War Office ordered the commanding officer of the $1^{\text {st }}$ Irish Guards to return to London in order to assess the possible impact of the Rising on his men. ${ }^{70}$ The War Office urgently needed to ascertain whether the uprising had affected the soldiers' loyalty during wartime. As Terence Denman has commented, the Easter Rising had aroused 'widespread suspicion of southern Irish troops among certain sections of the military high command', who openly confessed their mistrust towards regular Irish battalions. ${ }^{71}$

Pioneering studies have shown how Irish soldiers were 'too frequently portrayed as excitable, gullible and incorrigibly ill-disciplined'. ${ }^{72}$ These works have asserted that the 1916 Rebellion intensified pre-existing discrimination against Irish troops. ${ }^{73}$ After two gas attacks on 27 and 29 April 1916, several British officers alleged indiscipline on the part of the Irish soldiers to justify the high casualties. Denman has commented that the 'criticisms of the $16^{\text {th }}$ Division at Hulluch are typical of the malicious stories often spread about Irish soldiers'. ${ }^{74}$ Historians have concluded that 'post 1916 events in Ireland appear to have soured wider attitudes to Irish soldiers' ${ }^{75}$ However, most criticisms in the aftermath of the Rebellion targeted only the rebels. 'I hope they will shoot the Dublin rioters', lamented a captain in the $4^{\text {th }}$ King's Liverpool Regiment. ${ }^{76}$ A second lieutenant fighting with the $8^{\text {th }}$ York Regiment wrote that: 'I hope anyway they will have the sense to squash the Sinn Féiners once and for all'. ${ }^{77}$ While the Rising certainly heightened suspicion and contempt on the part of the War Office, front-line British men and officers did not in fact harass front-line Irish troops in the immediate aftermath of the uprising. Whereas such criticism initially targeted only the architects of the 1916 Rebellion, the 1917-18 conscription crisis resulted in the singling out of battalions for reproach. Only after the conscription crisis did British soldiers harass and taunt their Irish brothers-in-arms. In this respect, the role of the 1916 Rising has been overestimated, while the influence of the anti-conscription movement has been misunderstood.

Adopting a series of tactics ranging from minor provocations to serious defamation, several British officers and men purposely targeted Irish units from 1917 onwards. As Denman puts it, at the end of 1917 'a widespread campaign against the Catholic Irish soldier gathered momentum. He was seen as a potential rebel liable to be seduced by the wiles and plots of Sinn Féin and Germans' ${ }^{78}$

69 Douglas Gill and Dallas Golden (eds), The unknown army (London, 1985), p. 59.

${ }^{70}$ Regimental diary of $1^{\text {st }}$ Irish Guards, 2-16 June 1916 (T.N.A., WO 95/1216).

71 Denman, Ireland's unknown soldiers, p. 181.

72 Terence Denman, 'The Catholic Irish soldier in the First World War: the "racial environment"" in I.H.S., xxvii, no. 108 (Nov. 1991), p. 365.

73 Morrissey, 'A lost heritage', p. 72.

74 Denman, 'The Catholic Irish soldier', p. 358.

75 Bowman, The Irish regiments, p. 205.

76 Diary of Captain Mason, 27 Apr. 1916 (U.L.L., Liddle Collection, GS 1066).

77 Second Lieutenant Goodwin to his mother, 26 Apr. 1916 (ibid, GS 0644).

78 Denman, Ireland's unknown soldiers, p. 151. 
Some Irish units came in for suspicion and faced derogatory remarks from other British army units. Two by-elections in Ireland accentuated their resentment of Irish front-line troops. The threat of conscription benefited a Sinn Féin candidate, Count George Noble Plunkett, who won a parliamentary seat in North Roscommon in February 1917. Several weeks later, Sinn Féin secured another seat in the constituency of South Longford. ${ }^{79}$ More generally, as a majority of Irish M.P.s reasserted their opposition to conscription from 1917 onwards, open criticism of front line Irish troops ensued in some cases. As the conscription threat in Ireland reached its climax, the arrival of English volunteers into John Lucy's regiment, in July 1917, caused a degree of tension. An officer indirectly derided the presence of Irishmen in his unit. Contemptuous and condescending, he reiterated that he would inevitably be killed by a southern Irishman in France, who would 'furtively shoot' him. An English reserve officer felt less concerned by the Germans than by the possibility of being stabbed in the back by one of his own regiment's Irish soldiers. ${ }^{80}$ These comments aimed at destabilising the position of Irish soldiers and making them feel uncomfortable. In the mind of the reserve officer, Irish soldiers were rapidly becoming potential traitors.

However, there is evidence to suggest that the conscription crisis of 1918 rendered Irish soldiers particularly vulnerable to mistrust and abuse. In 1916, Ireland had been exempted from the military service bill, whereas conscription had been implemented in Great Britain. However, in April 1918, a series of factors convinced the British government of the necessity of imposing conscription in Ireland. Several factors helped to determine the decision of the British authorities: the disastrous losses suffered by the British army after the battles of the Somme in 1916 and Passchendaele in 1917, the peace treaty between Germany and Russia at the beginning of 1918, which in theory meant that all of the German divisions fighting in the east could be transferred to the west, and, finally, pressure from the French who were anxiously pleading with the British to send more troops to the Western Front. Furthermore, in such a delicate and final phase, British public opinion 'would simply not have accepted that Ireland would be exempted from compulsory military service'. ${ }^{81}$

Faced with the refusal of Irish M.P.s to support conscription in April 1918, a few British units denounced what, they considered, amounted to treason. Second Lieutenant Parr of the $2^{\text {nd }}$ Royal Scots Fusiliers wrote to his parents that he would 'sooner shoot an Irishman than a Hun!' ${ }^{12}$ G. Mortimer, a gunner with the $69^{\text {th }}$ Brigade, Royal Garrison Artillery, regretted that Ireland was 'a constant source of trouble' and deplored it could not 'be submerged for about five minutes'. ${ }^{83}$ Another English gunner thought that ' 90 per cent of the country [were] traitors and the other 10 per cent [were] neutral and [were] not on [their] side'. ${ }^{84}$ Several British soldiers condemned the selfishness of the Irish, 'the spoilt child of the family who kicks at England as a kid in a temper kicks his nurse' and felt that Irish citizens were duty bound to help the war effort. ${ }^{85}$

79 Gwynn, John Redmond's last years, pp 105-13.

${ }^{80}$ Lucy, There's a devil in the drum, p. 360.

81 Aan de Wiel, The Catholic church in Ireland, p. 205.

82 Second Lieutenant Parr to his parents, 23 May 1918 (U.L.L., Liddle Collection, GS 1227).

${ }_{83}$ G. Mortimer to his father, 26 May 1918 (ibid., GS 1136).

${ }^{84}$ Charles Winterbourne to a relative, 21 July 1918 (ibid., EP 094).

85 S. J. Wallis to a relative, 8 Oct.1918 (ibid., RNMN/WALLIS). 
The mass mobilisation against conscription in Ireland affected the views of the Irish held by many British soldiers.

Indeed, many regular Irish troops attached to British divisions experienced direct provocations. Harry Loughlin and his fellow countrymen of the $2^{\text {nd }}$ Royal Dublin Fusiliers felt disappointed to be the subjects of remarks 'by other regiments who up to the affair would not say anything to us' ${ }^{86}$ In May 1918, Father Gill acknowledged that 'the affairs in Ireland do not make things easier for us' ${ }^{87}$ Though he did not elaborate any further on the difficulties experienced by the $2^{\text {nd }}$ Royal Irish Rifles, the political turmoil affecting the island during the conscription crisis had a direct impact on front-line soldiers. Major Nightingale with the $1^{\text {st }}$ Royal Munster Fusiliers took exception to some British soldiers' negative comments and to their continual harassment of his men. In April 1918, he confessed: 'That's the hardest part of the whole show, to feel we've been through a rotten battle and wherever we go it's always -"There go the Sinn Féiners". "88 An English officer, Major Nightingale defended his units and did not hesitate to reprimand other British soldiers. His intention was to support Irish combatants and to counter the climate of abuse and mistrust to which they were exposed. His evidence indicates that numerous British soldiers openly questioned their fighting spirit and, implicitly, their loyalty. Sarcasm was sometimes combined with vicious, yet groundless, accusations. When the $1^{\text {st }}$ Royal Munster Fusiliers joined an English division, it was rumoured that all the officers and soldiers of the $16^{\text {th }}$ Division had 'put down their arms and walked over to the Bosch'. ${ }^{89}$ While the 1916 Easter Rising could be dismissed as a military operation conceived by a handful of republicans, with little support from the population, the conscription crisis gave expression to a defiance of British rule on the part of the whole of nationalist Ireland. ${ }^{90}$ Like the vast majority of British public opinion, British officers and men strongly resented Ireland's refusal to support the war effort at such a crucial moment.

Admittedly, few primary sources shed light on the oppressive environment which Irish soldiers had to endure, following the refusal of Irish M.P.s to support conscription. Instead of rushing to the conclusion that the absence of material evidence signifies that such examples were less representative than they might appear to be, one needs to understand why Irish units could not voice their opinions in the aftermath of the 1916 rebellion. Therefore, it is of crucial importance to address the changing composition of the three Irish divisions when, in the wake of major fighting, they were supplemented by English, Scottish and Welsh soldiers. After the Somme battles, 'the total manpower shortage in the three divisions ... was 17,750 men' on 20 September 1916. Preoccupied by the under-strength composition of the $16^{\text {th }}$ and $36^{\text {th }}$ Divisions, the War Office ordered that Irish battalions be brought up to strength with English replacements. ${ }^{91}$ The arrival of 'foreign' elements into

${ }^{86}$ Harry Loughlin to Monica Roberts, 17 June 1917 (D.C.A., Monica Roberts Collection, vol. i, RDFA/001/02).

87 Father Gill to provincial, 29 May 1918 (Irish Jesuit Archives, Correspondence of Father Gill, CHP 1/25).

${ }_{88}$ Major Nightingale to his mother, 24 Apr. 1918 (T.N.A., Nightingale papers, PRO 30/7/3).

${ }^{89}$ Ibid.

90 Aan de Wiel, The Catholic church in Ireland, p. 211.

91 Denman, Ireland's unknown soldiers, p. 139. 
Irish units changed the composition of the battalions. Whereas, in 1914, 'soldiers who were Irish-born comprised 86 per cent of these units, [they represented] only 56 per cent in $1918,{ }^{92}$ While nationalist units in these battalions might have been inclined to give open expression to their views if they had remained homogenous, the arrival of English conscripts in the ranks of the division might have had an inhibiting effect on them.

\section{VI}

To appraise the impact of internal upheavals in Ireland on Irish troops exclusively in the light of the 1916 uprising is inadequate for a comprehension of the complex and protean influence of internal turmoil in Ireland on frontline units. The present article has illustrated the need to broaden the chronological scope of inquiries, in order to better evaluate the consequences of the 1914 home rule crisis on the treatment of Irish P.O.W.s, and to extend analysis of the effects of the 1917-18 conscription crisis on both Irish and British front-line combatants. All in all, the internal pre-war political situation in Ireland moulded the enemy's view of Irish troops. In order to destabilise Entente powers with the help of foreign nationalities, German authorities took advantage of the 1914 home rule crisis and sought to persuade Irish P.O.W.s to betray the British. In short, political unrest in Ireland shaped the enemy's attitudes towards the Irish even before the insurrection in Ireland. The shifting nature of the responses on the part of Irish units following the 1916 Rising 'encapsulate[s] the fundamental ambiguity of Ireland's relationship with Britain'. ${ }^{93}$ It exposed the multifaceted motivations and expectations that had inspired Irish recruits to join the war effort. While British units did indeed register the consequences of the Rebellion, they began targeting their Irish brothers-in-arms after Irish M.P.s reaffirmed their opposition to conscription. With the deepening of the political crisis, a number of Irish battalions attracted suspicion, leaving soldiers open to displays of resentment and mistrust on the part of their British comrades. It is essential that historians take account of the hardships the Irish endured at the hands of the Germans, the despondency of Irish units in the aftermath of the Rising, and also the pressures they were placed under by their fellow soldiers during the conscription crisis in Ireland. The impact of crucial events such as the 1914 home rule crisis and the conscription crisis have tended to be overlooked, left in the shadow of the overwhelming influence of the 1916 Rebellion.

92 Grayson, Belfast boys, p. 102.

93 Morrissey, 'A lost heritage', p. 83. The author of the article would like to express his gratitude to the French Ministry of Defence and to the Irish Research Council for their funding, without which it would have been impossible to conduct his research. 